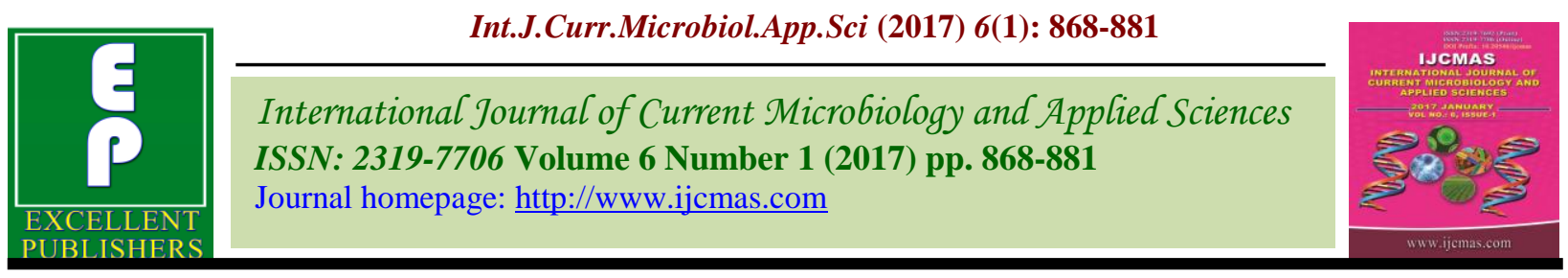

Original Research Article

http://dx.doi.org/10.20546/ijcmas.2017.601.103

\title{
Production of Wine from Fermentation of Grape (Vitis vinifera) and Sweet Orange (Citrus seninsis) Juice using Saccharomyces cerevisiae Isolated from Palm Wine
}

\author{
Bobai Mathew ${ }^{1}$, Mohammed Sani Sambo Datsugwai ${ }^{1}$, \\ Emmanuel Silas David ${ }^{2}$ and Ugboko Harriet ${ }^{3}$
}

${ }^{1}$ Department of Microbiology, Faculty of Science, Kaduna State University, Kaduna, Nigeria

${ }^{2}$ Nigeria Institute of Leather and Science Technology (NILEST), Zaria, Nigeria

${ }^{3}$ Department of Biological Sciences, Covenant University, Canaanland, Ota, Ogun State, Nigeria

*Corresponding author

\section{A B S T R A C T}

\section{Keywords}

Wine, Grape, Sweet Orange, Saccharomyces cerevisiae,

Fermentation, Physicochemical parameters.

Article Info

Accepted:

28 December 2016

Available Online:

10 January 2017
Production of wine from fermentation of grape (Vitis vinifera) and sweet orange (Citrus seninsis) juice using Saccharomyces cerevisiae isolated from palm wine was investigated. The isolation of Saccharomyces cerevisiae from palm wine, fermentation of grape and orange juice, and determination of physicochemical and microbiological parameters were carried out using standard procedures. Proximate analysis of the grape and orange revealed high moisture content ranging from 82.43 to $85.48 \%$. During fermentation of the grape and orange fruit must, the $\mathrm{pH}$ values ranged from 3.27 to 3.50 , percentage titratable acidity from 0.020 to 0.061 , percentage volatile acidity from 0.045 to 0.15 , and specific gravity values from 1.010 to 1.100 . The fermentation recorded higher total viable yeast count from grape $\left(2.5 \times 10^{6}\right.$ to $13.0 \times 10^{6}$ $\mathrm{cfu} / \mathrm{ml})$ than orange $\left(2.5 \times 10^{6}\right.$ to $\left.12.5 \times 10^{6} \mathrm{cfu} / \mathrm{ml}\right)$. Percentage alcohol values observed were $14.6 \%$ and $12.6 \%$ for grape and orange wines respectively. There was no significant difference $(\mathrm{P}>0.05)$ for specific gravity and percentage alcohol values, while for $\mathrm{pH}$, temperature and volatile acidity values there was Significant difference $(\mathrm{P}<0.05)$. Sensory evaluation revealed that both wines had acceptable aroma/flavor and taste. This study indicates that Saccharomyces cerevisiae from palm wine could be used for fruits wine production and other industrial applications.

\section{Introduction}

Non-availability and relatively high cost ofmost effective commercially alcoholic fermentative Saccharomyces cerevisiae strains becomes a major constrain in development and sustaining local industrial fermentation process in developing countries. Hence, there is need for search of indigenous strain that could be used as an alternative. Purified yeasts from palm wine showed highly viable cells and good metabolic activity during grape must fermentation (Ukwuru and Awah, 2013), and must studies on palm wine have reported its potentials as sources of yeast isolates for the fermentation industries because it is a nutritionally rich medium for the growth of microorganism, among which is the Saccharomyces cerevisiae (Nwachukwu et al., 2006, 2008; Nanknean, 
2010). Ukwuru and Awah (2013) reported Saccharomyces cerevisiaestrains isolated from palm wine to have high ethanol tolerance - a unique properties of the yeast that makes it exploitable for industrial applications.

Grape wine is perhaps the most economically important fruit juice alcohol (Kelebek et al., 2013) and because of the commercialization of the product for industry, the process has received most research attention. However, any fruit with a good proportion of sugar may be used for wine production (Alobo \& Offonry, 2009). In Nigeria, there is abundance of tropical fruit including sweet oranges, which are highly perishable, and susceptible to bacterial and fungal contamination; as a result, they fail to reach the market due to spoilage, mechanical damage and over ripeness (Ihekoroye and Ngoddy, 1985). Besides, these fruits are difficult to keep for considerable length of time; hence the ripe fruits are utilized either as fresh or processed into juice and specialty products (Oyeleke and Olaniyan, 2007).

High rate wastage of these fruits especially at their peak of production during their season necessitates the need for alternative preservation food forms towards an enhanced utilization of these fruits. The production of wines from common fruits could help reduce the level of post-harvest losses and increase variety of wines (Okoro, 2007; Alobo and Offonry, 2009).

Utilizing palm wine yeast for industrial wine production process requires a comprehensive knowledge of their technological and alcoholic fermentative performance. Therefore, this study aimed at determining the effectiveness of palm wine Saccharomyces cerevisiae strain in production of wine from fermentation of grape (Vitis vinifera) and orange (Citrus seninsis) juice

\section{Materials and Methods}

\section{Collection of samples}

Fresh palm wine samples were collected from tapped sources into sterile stomacher bags from Kagoro in Kaura Local Government Area, Kaduna State, Nigeria and was transported in ice pack thermo-flask to Kaduna State University Microbiology Laboratory for the isolation of yeast.

\section{Isolation and Identification of Yeast from Palm Wine}

Sabouraud Dextrose Agar (SDA) was prepared according to manufacturer's instruction and supplemented with $50 \mathrm{mg} / \mathrm{L}$ Chloramphenicol for selective enumeration of yeast. Serial dilution of the palm wine was carried out and inoculated using pour plate techniques. Pure culture was made on yeast glucose agar plates. Microscopic examination of the isolate was carried out using wet mount method according to Thais and Danilo (2006)

\section{Carbohydrates Utilization Test on Yeast Isolate from Palm Wine}

One (1) \% each of glucose, fructose, sucrose, lactose, xylose, mannitol, raffinose, galactose and maltose sugar were prepared using Yeast fermentation broth and dispensed $10 \mathrm{ml}$ volume into clean test tubes. Clean Durham tubes were introduced into the tubes, displaced all bubbles and then autoclave at $121^{\circ} \mathrm{C}$ for 15 minutes and allowed to cool.

The sterile broth was inoculated with $0.2 \mathrm{ml}$ yeast culture broth and incubated at room temperature for 24-72 hours and observed evidence of fermentation. Presumptive Saccharomyces cerevisiae isolate was confirmed using Analytical Profile Index (API 20 CAUX, BIOMAX). 


\section{Percentage Ethanol Tolerance Test of Yeast Isolate}

The test was carried out according to Alobo and Offonry (2009).Where $2 \%, 5 \%, 8 \%, 11$ $\%, 14 \%, 16 \%$ and $19 \%$ of ethanol in molten yeast glucose agar medium were prepared and pour in triplicates plates. The plates were inoculated with the pure culture yeast isolates and incubated at room temperature for 24-72 hours.

\section{Proximate Analysis of the Fruits}

\section{Determination of Percentage Moisture Content}

Five (5) $\mathrm{g}$ of the sample was weighed into Petri dish and placed in air draught oven at $100{ }^{0} \mathrm{C}$ for 1 hour. The Petri dish was then weighed after cooling. The process was repeated thrice until a constant weight was obtained. Loss in weight was calculated as the percentage moisture content (Moronkola et al., 2011) and this was expressed by the following formula:

$\%$ moisture $=\frac{\text { loss in weight due to dryness } x 100}{\text { Weight of sample taken }}$ $=\frac{\mathrm{w}_{2}-\mathrm{W} 3 \times 100}{\mathrm{w}_{2}-\mathrm{W} 1}$

Where; $\mathrm{W}_{1}=$ weight of empty crucible, $\mathrm{W}_{2}=$ weight of crucible + sample before drying, $\mathrm{W}_{3}=$ weight of crucible + sample after attaining constant weight on drying

\section{Determination of Percentage Ash Content}

This was carried out as describe by Moronkola et al. (2011), where porcelain crucible with lid was ignited in a hot Bunsen burner flame and transferred into desiccator to cool and the crucible was weighed. $5 \mathrm{~g}$ of the sample was accurately weighed into the crucible and gently placed in the muffle furnace set at $600{ }^{\circ} \mathrm{C}$ for 4 hours. The crucible was place in desiccator to cool. The ashed sample in the crucible was weighed after cooling without the lid and the process repeated thrice for the sample. The result was calculated using the following formula:

$\%$ Ash content $=\frac{\mathrm{W}_{3}-\mathrm{W}_{1}}{\mathrm{~W}_{2}-\mathrm{W}_{1}} \times 100 \quad$ Where,

$\mathrm{W}_{1}=$ weight of empty crucible,

$\mathrm{W}_{2}$ = weight of crucible + sample before ashing

$\mathrm{W}_{3}=$ weight of crucible + sample after ashing

\section{Determination of Percentage Crude Fat}

Two (2) g of the sample was transferred into a beaker and weighed as $\mathrm{W}, 10 \mathrm{ml}$ of water was added, and the solid was dispersed by agitating it. $10 \mathrm{ml}$ of concentrated hydrochloric acid was added and immersed in a boiling water bath until the solid particle dissolved and the mixture become brown in colour. This was allowed to cool and $10 \mathrm{ml}$ of alcohol added and agitated vigorously. A dried clean flask was weighed and recorded as $\mathrm{W}_{1}$ and the ether layer was transferred into the flask and placed in a boiling water bath to evaporate the ether. The extraction was repeated by adding $50 \mathrm{ml}$ diethyl ether in order to evaporate the ether living the fat behind. The fat and the flask was weighed and recorded as $\mathrm{W}_{2}$, then the fat content was calculated as follows:

$\%$ fat $=\frac{\mathrm{W} 2-\mathrm{W} 1}{\mathrm{~W}} \times 100$

Where, $\mathrm{W}=$ weight of the sample

$\mathrm{W}_{1}=$ weight of dried flask

$\mathrm{W}_{2}=$ weight of dried flask fat residue. 


\section{Determination of Percentage Crude Protein Content}

Five (5) $g$ of sample was weighed on ash less filter paper. The paper with sample was folded and dropped into the digestion flask. $20 \mathrm{ml}$ of sulphuric acid $\left(\mathrm{H}_{2} \mathrm{SO}_{4}\right)$ and 4 pieces of granulated zinc were added and shook, then heated gently inside a fume cupboard for 6 hours. The content in the flask was allowed

$\%$ nitrogen content $\left(\mathrm{N}_{2} \%\right)=\underline{0.014 \times \mathrm{M} \mathrm{x} \mathrm{V} \mathrm{x} 100 \times \text { D.F }}$

Weight of sample

Where, $\mathrm{M}=\mathrm{is}$ the actual molarity of acid

$\mathrm{V}=$ is the volume of acid used

$\mathrm{D} . \mathrm{F}=$ is the volume ratio of solution

$\%$ protein content $=$ Nitrogen content $\mathrm{x}$ conversion factor based on the sample

\section{Determination of Total Carbohydrate Content}

The total carbohydrate content of the sample was obtained as described by Moronkola et al., (2011), where the results from fat, protein, moisture and ash content analyses were sumup and the carbohydrate content was calculated as follows:

$100 \%$ (\% moisture $+\%$ protein $+\%$ fat $+\%$ ash).

\section{Fermentation of the Fruits Must}

The fermentation tank was washedand 1litre pasteurized fruit must was transferred aseptically to the fermentation tank, $0.2 \mathrm{ml}$ of $10 \%$ sodium metabisulphite mixed well follow by addition of $2 \mathrm{ml}$ of $1.0 \times 10^{6}$ cells $/ \mathrm{ml}$ of the standard yeast inoculum to the tank and shook to dispersed evenly in the tank. This was kept at room temperature in a sterile laminar flow unit for fermentation up to 5 days (Butz, 2007). to cooled. The solution was diluted with distilled water and transferred into $800 \mathrm{ml}$ Kjehldah flask. $100 \mathrm{ml}$ of $40 \% \mathrm{NaOH}$ was added and distilled. This followed by titration against $0.05 \%$ of boric acid solution using methyl red as indicator. The protein content was estimated from the amount of nitrogen present in the sample.

\section{Determination of $\mathrm{pH}$}

The $\mathrm{pH}$ was determined directly during fermentation using a digital $\mathrm{pH}$ meter (model pHS -25) as described by Ochai and Kolhatkar (2008).

\section{Determination of Titratable Acidity}

The titratable acidity was determined during the fermentation based on Association of Analytical Communities International (2000) method 962.12. The sample was degassed by agitation. The $\mathrm{pH}$ of the water was adjusted by adding $1 \mathrm{ml}$ phenolphthalein indicator for each $200 \mathrm{ml}$ of water. $0.1 \mathrm{~N} \mathrm{NaOH}$ was used to neutralize the water to a distinct but faint pink colour (desired endpoint). $5 \mathrm{ml}$ of the degassed sample was pipette into a $250 \mathrm{ml}$ conical flask, $100 \mathrm{ml}$ of distilled water was added to the flask. The flask was swirled to release any remaining $\mathrm{CO}_{2} .0 .1 \mathrm{~N} \mathrm{NaOH}$ was titrated against the content of the flask until the pale pink colour endpoint which persist for 30 seconds was achieved. Titratable acidity was calculated as follows: 
$\%$ Tartaric Acid $=\frac{(\text { ml alkali }) x(\text { normality of alkali }) x .5}{\text { weight of sample }(\mathrm{mls} \text { of sample })}$

\section{Determination of Volatile Acidity}

Volatile Acidity was determined during the fermentation based on Association of Analytical Communities International ( 2000) method 962.12. The sample was degassed by agitation. The $\mathrm{pH}$ of the water was adjusted by adding $1 \mathrm{ml}$ drop of phenolphthalein indicator for each $200 \mathrm{ml}$ of water. $0.05 \mathrm{~N}$ $\mathrm{NaOH}$ was used to neutralize the water to a distinct but faint pink colour (desired endpoint). $5 \mathrm{ml}$ of the degassed sample was pipette into a $250 \mathrm{ml}$ conical flask, $100 \mathrm{ml}$ of distilled water was added to the flask. The flask was swirled to release any remaining $\mathrm{CO}_{2} .0 .05 \mathrm{~N} \mathrm{NaOH}$ was titrated against the content of the flask until the pale pink colour endpoint which persist for 30 seconds was achieved and calculated as follows:

$$
\% \text { Acetic acid }=\frac{(\text { ml alkali }) x(\text { normality of alkali) } x .0}{\text { weight of sample (mls of sample })}
$$

\section{Determination of Specific Gravity (S.G)}

This was carried out using relative density bottle, where the bottle was wash with tap water and dried. The surface of bottle was further clean with ethanol and allowed to dried again. Using an electronic balance, the

\section{Specific gravity $=$}

$\frac{\text { wt of volume of sample (M1-Mo) }}{\text { wt of an equal volume of water (M2-Mo) }}$

\section{Measurement of Temperature}

One hundred and twenty $(120)^{0} \mathrm{C}$ mercury bulb thermometer was inserted to the side arm of the fermentation tank through a sterile rubber cork. The periodic temperature change during fermentation was recorded.

\section{Determination of Alcohol Content}

This was determined using the $\%$ Sugar/Specific gravity/Brix/ PA equivalent table according to AOAC (2000).

Determination of Total Colony Yeast Count

Sabouraud dextrose agar supplemented with $50 \mathrm{mg} / \mathrm{L}$ Chloramphenicol was used for selective enumeration of yeast according to Steger and Lambrechts (2010) and Mir and empty weight of the bottle was determined $\left(\mathrm{M}_{0}\right)$. The weight of the bottle plus $5 \mathrm{ml}$ of the wine sample (M1) was determined, follow by the weight of the empty bottle plus $5 \mathrm{ml}$ of distilled water (M2), and the specific gravity then calculated from these values as follows:

Mohammed (2014). Serial dilution of the wine was carried out and inoculated using pour plate techniques. Pure culture was made on yeast glucose agar plates. Colonies from the plates of $10^{-6}$ dilution were count using colony counter.

\section{Sensory Evaluation of the Fermented Fruits Wines}

The sensory evaluation of the fermented fruits wines was made by ten panelist comprising of staff and students of Microbiology Department, Kaduna state University, Kaduna. The samples were evaluated using a standard "Scoring Difference Test" method (Hodgson, 2008) following the instructions provided in the sensory evaluation questionnaires. 


\section{Data Analysis}

Data generated were subjected to statistical analysis using one-way Analysis of Variance (ANOVA) and a significant difference was considered when $\mathrm{P}<0.05$

\section{Results and Discussion}

\section{Results}

\section{Isolation and Identification of Saccharomyces cerevisiae from Palm Wine}

The conventional sugar fermentation and API characterization revealed the Saccharomyces cerevisiaeidentified to be positive to glucose, sucrose, mannitol, maltose, galactose, saccharose, rafinnose and $\mathrm{N}$ - acetyl $\mathrm{D}$ glucosamine. And the alcohol tolerance test of the isolate revealed high ethanol tolerance up to $16 \%$.

\section{Proximate composition of grape and orange fruits Must}

Table 1 showed the proximate composition of grape and orange fruits with orange fruit must having low protein content, total carbohydrate, but high moisture content compared to grape fruit must.

\section{Variation in Physicochemical and Microbiological Parameters during Fermentation}

The $\mathrm{pH}$ of the must for both the grape and the orange fruits were 3.64and 3.55 respectively. During fermentation, the $\mathrm{pH}$ values obtained ranges from 3.27 to 3.50 for both fruits, and showed statistical significant difference $(\mathrm{P}<0.05)$ between the $\mathrm{pH}$ values (Figure 1).

The total titratable acidity of the must before fermentation were 0.023 and 0.026 for grape and orange fruits respectively (Figure 2). During fermentation, the titratable acidity values obtained ranges from 0.020 to 0.051 with fluctuation, and there was no statistical significant difference $(\mathrm{P}>0.05)$ between the total titratable acidity values during fermentation of both fruits must.

For the volatile acidity, Figure 3 showed the volatile acidity of the must before fermentation to be 0.075 and 0.045 for grape and orange fruits respectively. During fermentation, the volatile acidity obtained ranges from 0.087 to 0.150 with fluctuation for grape juice.

Similarly, the orange fruits recorded a range from 0.039 to 0.075 with a record of 0.045 at 12hours, 0.075 at 84hours and 0.039 at 120hours. There was significant difference $(\mathrm{P}<0.05)$ between the volatile acidity values during fermentation of both the fruits must.

Figure 4 revealed that the temperature of the fruits must before fermentation were $19^{\circ} \mathrm{Cand}$ $25^{\circ} \mathrm{C}$ for grape and orange respectively. The temperatures rise during fermentation of the grape to $23^{\circ} \mathrm{C}$ at 72 hours, then decreases to $21^{\circ} \mathrm{C}$ at 120 hours, while for the orange, the temperature rises from $27^{\circ} \mathrm{C}$ at 12 hours to $31^{\circ} \mathrm{C}$ at 48 hours and further decreases to $30^{\circ} \mathrm{C}$ at 120hours. The highest temperature recorded was $31^{\circ} \mathrm{C}$ at 48 hours during the fermentation of the orange fruit must and there was significant difference $(\mathrm{P}<0.05)$ between the temperature values.

The specific gravity of the must before fermentation were revealed in figure 5 with 1.11 and 1.092 for grape and orange respectively. During the fermentation, there was an observed order of decreases with ranges from 1.100 to 1.010 and 1.086 to 1.000 for grape and orange respectively from 12 hours to 120hours; and there was no significant difference $(\mathrm{P}>0.05)$ between the specific gravity values during fermentation of both the grape and orange fruits must. 
The percentage alcohol obtained during the fermentation period was $14.6 \%$ and $12.6 \%$ for grape and oranges respectively (Figure 6). The percentages of alcohol during the fermentation increases from 12hours to the 120 hours. The grape fermentation recorded the highest percentage alcohol (14.6\%) compared to that of the orange $(12.6 \%)$ and there was no statistical significant difference $(\mathrm{P}>0.05)$ between the percentage alcohol values recorded during the fermentation.

There was no growth from the pasteurized fruits must before the fermentation. After inoculation of sterile must and the onset of the fermentation, total viable yeast count $(\mathrm{cfu} / \mathrm{ml})$ increases from $2.5 \times 10^{6}$ at 12 hours to 13.0 $\mathrm{x} 10^{6}$ at 84 hours and then decline to $10.8 \mathrm{x}$ $10^{6}$ at 120 hours during fermentation of grape juice, while orange juice fermentation recorded $2.5 \times 10^{6}$ at 12 hours to $12.5 \times 10^{6}$ at 60hours and then decline to $10.5 \times 10^{6}$ at 120hours. The fermentation of grape recorded the highest total viable yeast count $\left(13.0 \times 10^{6}\right.$ $\mathrm{cfu} / \mathrm{ml})$ compared to orange $\left(12.5 \times 10^{6}\right.$ $\mathrm{cfu} / \mathrm{ml})$.

The sensory evaluation of the wines produced from the fermentation of grape and orange revealed no significant difference $(\mathrm{P}>0.05)$ between the wines in terms of alcoholic, yeast and tingly (carbonations) flavor. While in terms of fruity and sweet flavor evaluation, both wines revealed significant difference $(\mathrm{P}<0.05)$ with grape wine having much fruity sweet flavour compared to that of orange wine. In regard to taste, the wines revealed acceptable taste with no significant difference $(\mathrm{P}>0.05)$ between the fruits wine.

The Saccharomyces cerevisiae isolated from the palm wine samples had high ethanol tolerance up to $16 \%$, implying that the yeast strain can remain metabolically active in the fermentation medium and tolerate up to $16 \%$ alcohol produce during the fermentation period. This is similar to findings of Bechem et al. (2007) who reported that high percentage ethanol tolerance is a property that can be exploited for industrial applications. The results of the proximate composition revealed high percentage moisture content (82.43 to $85.48 \%$ ) for both the fruits. And this according to Okaka (2010) accounts for their high perishable nature and their short shelf life under normal storage condition. The fruit also revealed reasonable amount of total carbohydrate (11.14 to $14.23 \%)$ which invariably accounts for their high caloric values suggesting the presence of energy source for metabolic activity of the yeast. Low protein content (0.09 to $0.53 \%)$ was recorded. And according to Okegbabile and Taiwo (2009), that the low protein and mineral content of the fruit as reported in this study is a probable indication that fear of over accumulation due to consumption of the fruits do not arise. The result of the proximate composition of the fruits in this investigation is in agreement with the general case for fruits as reported by Pearson (2007). The present study revealed low $\mathrm{pH}$ values (3.27 to3.50) in the fruit wines at fermentation period. The trend of the changes in $\mathrm{pH}$ revealed consistent increases in acidity of the fruit wines throughout the period of fermentation. Chilaka et al. (2010) also recorded a similar $\mathrm{pH}$ ranged of 3.0 to 4.8 during fermentation of passion fruit, water melon and pineapple fruits juice using commercial Saccharomyces cerevvisiae. Studies have shown that during fermentation of fruits, low $\mathrm{pH}$ is inhibitory to the growth of spoilage organisms but creates conducive and competitive advantage environment for the growth of desirable organisms (Reddy and Reddy, 2009). Temperature of the fruit wines throughout the period of fermentation ranged from 19 to $31^{\circ} \mathrm{C}$. A similar observation has been reported by Reddy and Reddy(2009) where temperature values for quality mango fruit wine production was5 to $30{ }^{0} \mathrm{C}$. The rises in 
temperature recorded may be due the catabolic processes of sugars by yeast cells resulting in metabolic heat that ultimately increased the temperature as reported by Ukwuru and Awah (2013). The production of heat during fermentation as an exothermic process means that the temperature of the fermentation in the vessel rises.

Malic acid and tartaric acid are the primary acids in grape wines, and these acids have direct influence on growth and vitality of yeast during fermentation (Bellman and Gallander, 2009). The measure of the amount of acidity in wine is known as the "titratable acidity or total acidity" which refers to the test that yields the total of all acids present, while the strength of the acidity is measured according to $\mathrm{pH}$, with most wines having $\mathrm{pH}$ values between 2.9 and 3.9. Generally, the lower the $\mathrm{pH}$ the higher the acidity in the wines (Bellmanand Gallander, 2009). Also, acetic acid is a two-carbon organic acid produced in wine during or after the fermentation period. It is the most volatile of the primary acids associated with wine and is responsible for the sour taste (Robinson, 2006). The current investigation revealed that the specific gravity values ranged from 1.100 to 1.010 and 1.086 to 1.000 for grape and orange respectively, and there was no significant difference $(\mathrm{P}>0.05)$ between the values during fermentation of both fruits must. Steady decreases in specific gravity values was observed to be inversely related to increases in alcohol content, as remarkable amount of alcohol was produced from the fruit wines during fermentation with the test yeast.

Generally, the percentage alcohol produced from the respective fruits at the end of fermentation with the same yeast was recorded as $14.6 \%$ and $12.6 \%$ for grape and pineapple respectively and there was no significant difference $(\mathrm{P}>0.05)$ between the values. Similar findings by Chilaka et al. (2010) revealed that during fermentation of passion fruit, water melon and pineapple fruits must, the percentage alcohol content ranged from 10.14 to $12.8 \%$. This however, according to Okunowo and Okotore (2005) is comparable with moderate grape wine. The fermentation recorded higher total viable yeast count from grape $\left(2.5 \times 10^{6}\right.$ to $13.0 \times 10^{6}$ $\mathrm{cfu} / \mathrm{ml})$ compared to orange $\left(2.5 \times 10^{6}\right.$ to 12.5 $\left.\mathrm{x} 10^{6} \mathrm{cfu} / \mathrm{ml}\right)$. The yeast viable count of this study showed rapid increases during the first three days (72hours) fermentation and thereafter, a sharp decline. This is probably because in the first three days, there was much nutrients (fermentable sugars) available to the yeast and active enzymes for the metabolic activity of the yeast; which might be responsible to the increase in the yeast count. In the contrary, nutrient depletion in the fermenter, high cells density, and possible presence of toxic metabolic by- products could be responsible for the decline in the yeast count after the third day of the fermentation. Also, consistent increase in the alcohol concentration may result to the yeast cell membranes becoming susceptible to rapture by the ethanol, the possible contributing factor for decline in growth recorded on the third day of fermentation.

High alcohols are known to be important precursors for the formation of esters, which are associated with pleasant aromas (Clemente et al., 2007). Report have shown that the fermentation of fruits juices using yeast from different sources creates variety in flavor and varying levels of alcoholic contents in wines. More so, that alcoholic fermentation leads to a series of by-products in addition to ethanol; and that some of the byproducts include carbonyl compounds, alcohols, esters and acids, all of them influencing the quality of the finished product. The sensory evaluation of the fruits wines generally revealed acceptable aromas and taste. 
Table.1 Proximate composition of grape and orange fruits before fermentation

\begin{tabular}{lllllllll}
\hline S/N & Sample & $\begin{array}{l}\text { Moisture } \\
(\boldsymbol{\%})\end{array}$ & $\begin{array}{l}\text { Ash } \\
(\boldsymbol{\%})\end{array}$ & $\begin{array}{l}\text { Fat } \\
(\boldsymbol{\%})\end{array}$ & $\begin{array}{l}\text { Protein } \\
(\boldsymbol{\%})\end{array}$ & $\begin{array}{l}\text { Total } \\
\text { Carbohydrate (\%) }\end{array}$ & $\begin{array}{l}\text { Crude } \\
\text { Fibre } \\
(\boldsymbol{\%})\end{array}$ & $\begin{array}{l}\text { Energy } \\
(\text { Kcal/g) }\end{array}$ \\
\hline $\mathbf{1}$ & ORANGE & 85.48 & 3.0 & 0.295 & 0.09 & 11.14 & 4.25 & 47.58 \\
& & & & & & & & \\
$\mathbf{2}$ & GRAPE & 82.43 & 2.27 & 0.535 & 0.53 & 14.23 & 2.43 & 63.90 \\
\hline
\end{tabular}

Fig.1 Variation in $\mathrm{pH}$ during Fermentation of the Fruits Must

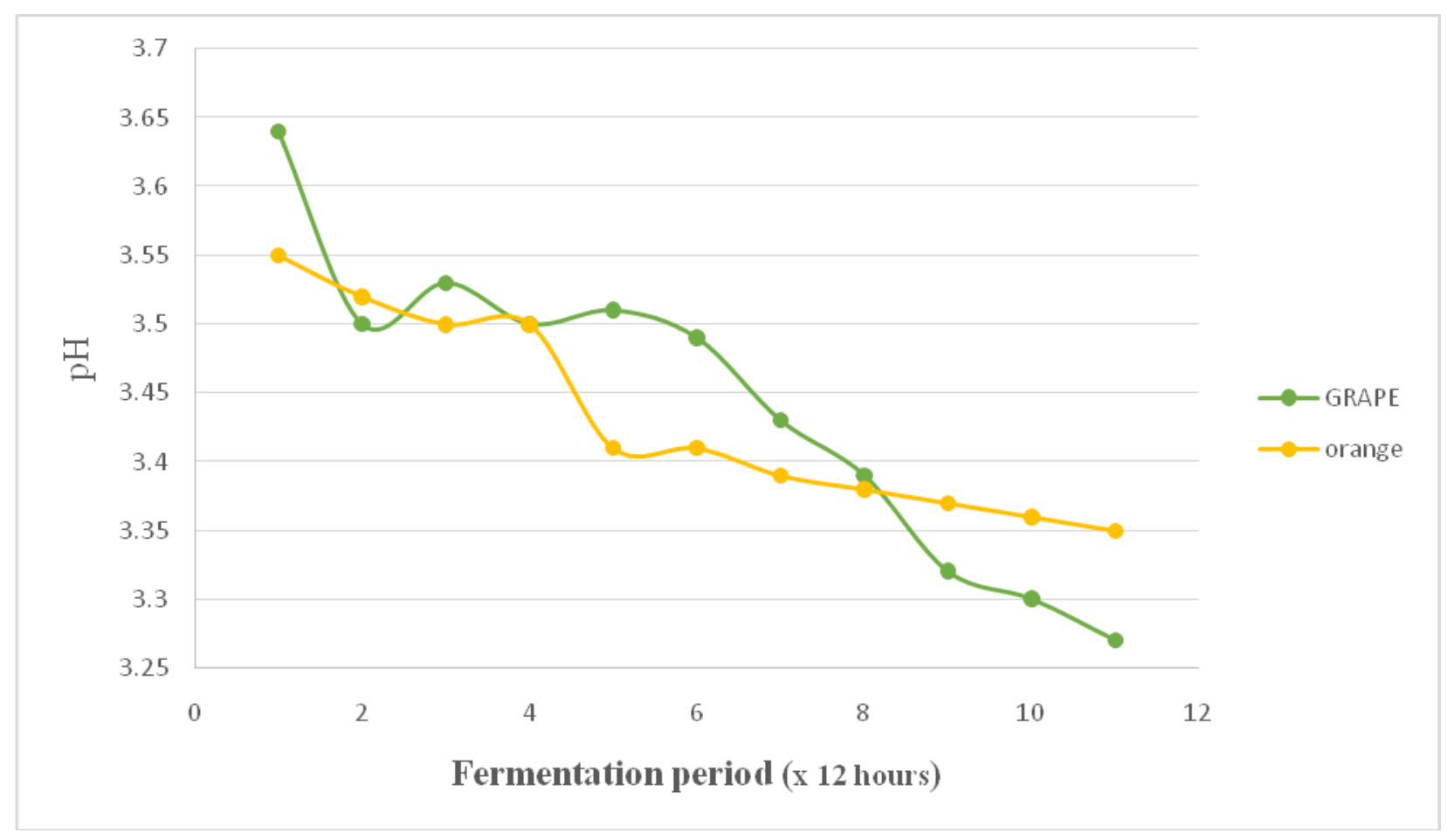


Fig.2 Variation in Titratable Acidity during Fermentation of the Fruits Must

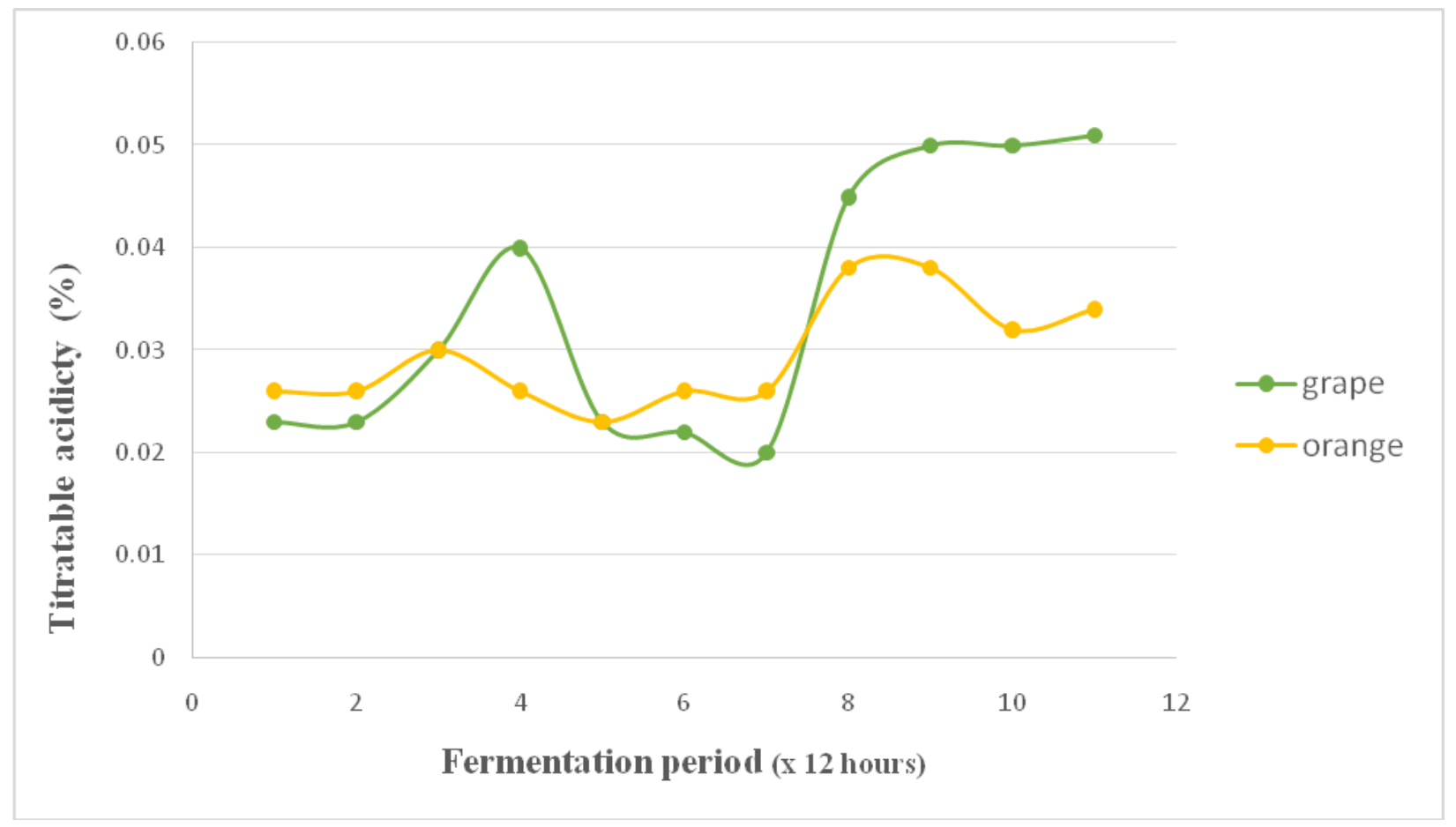

Fig.3 Variation in Volatile Acidity during Fermentation of the fruits Must

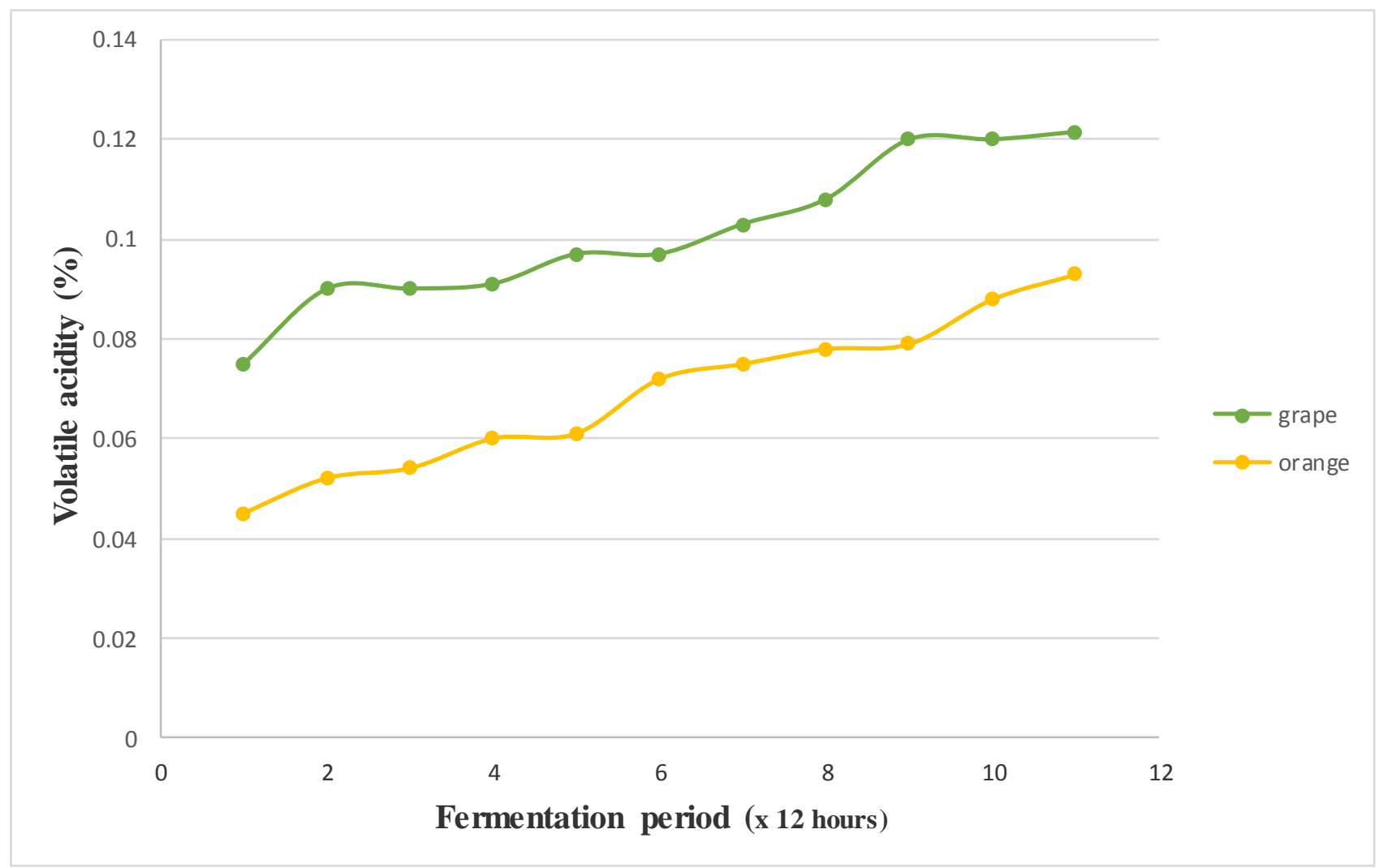


Fig.4 Variation in Temperature during Fermentation of the Fruits Must

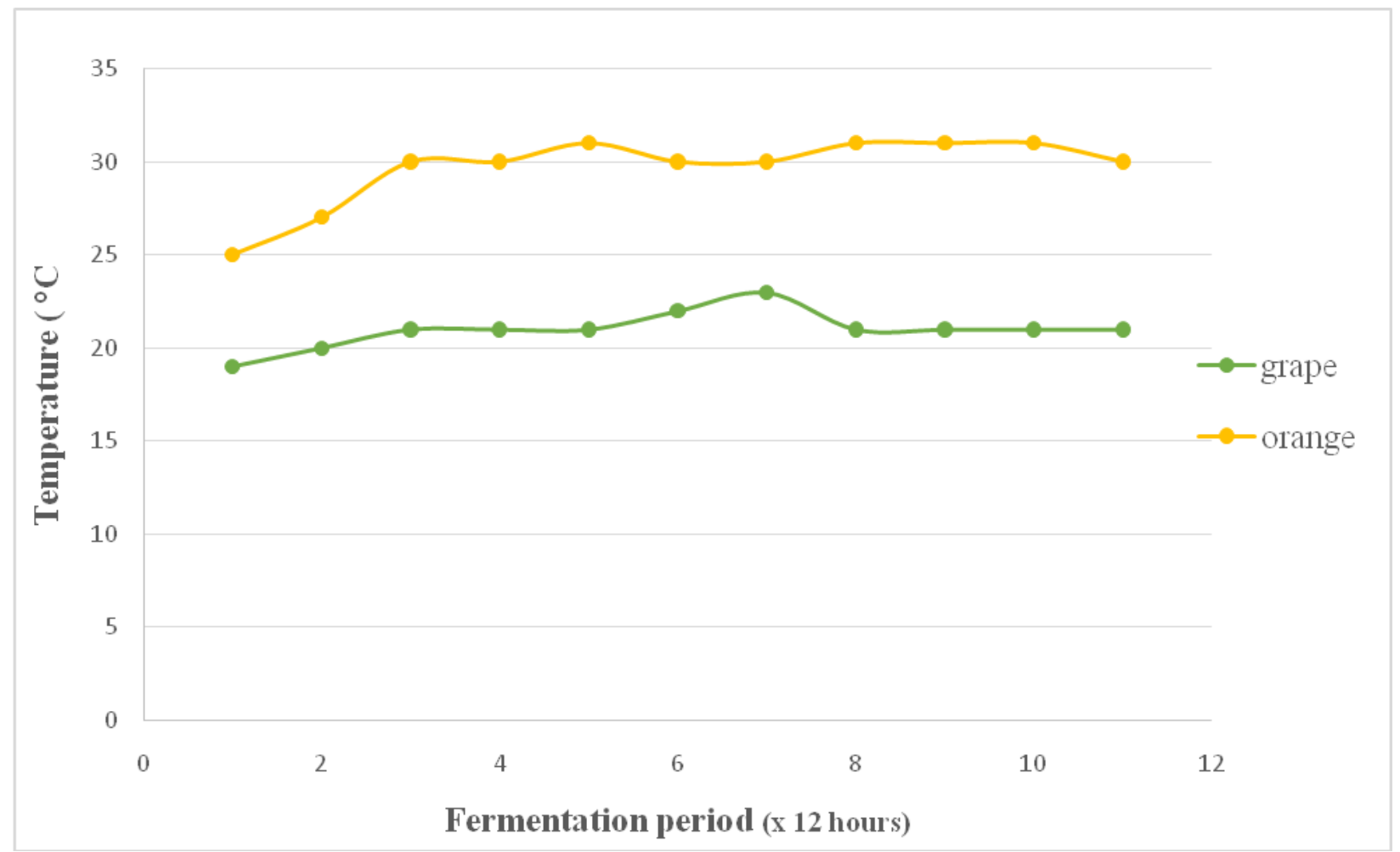

Fig.5 Variation in Specific Gravity during Fermentation of the Fruits Must

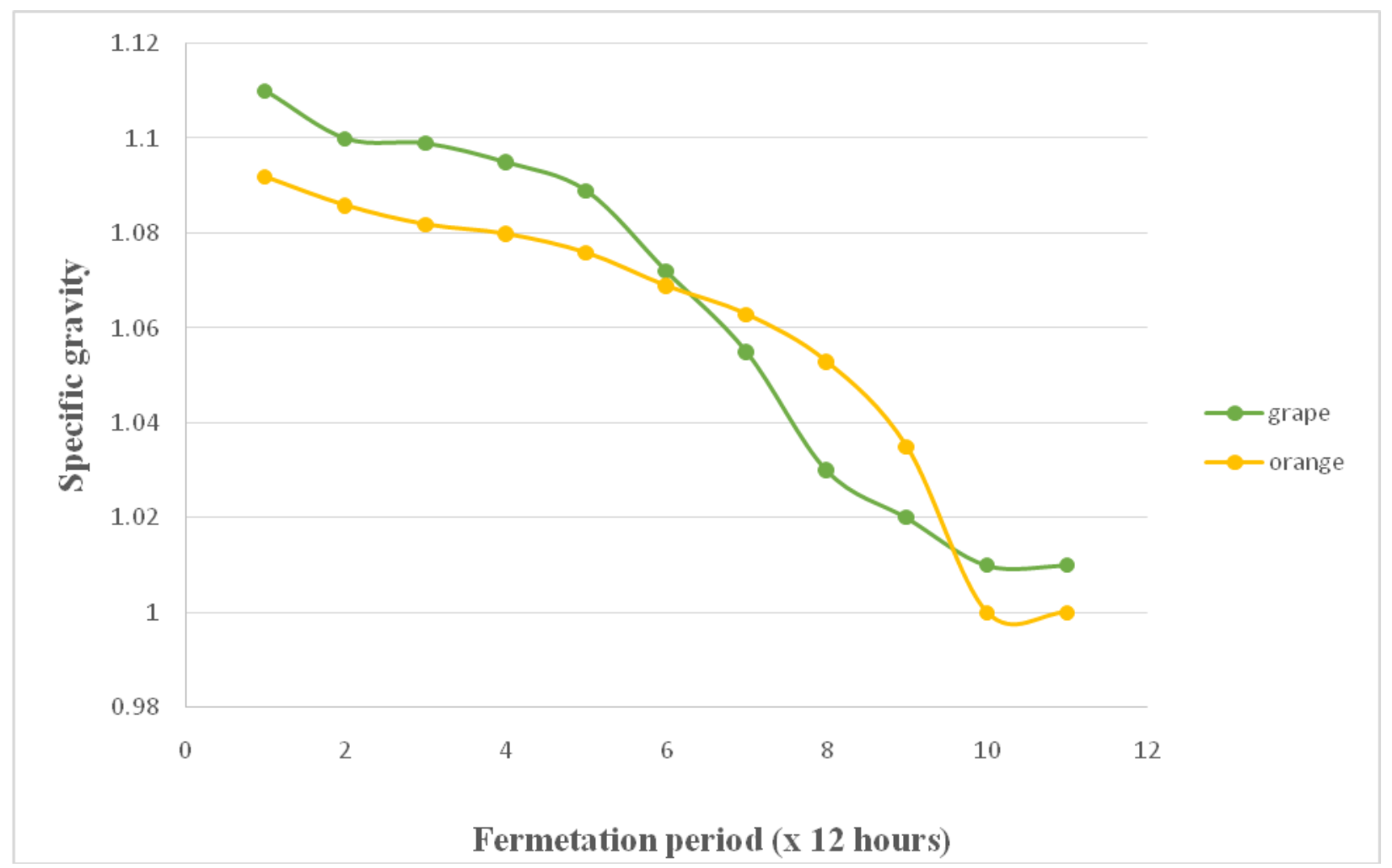


Fig.6 Variation in Percentage Alcohol during Fermentation of the Fruits Must

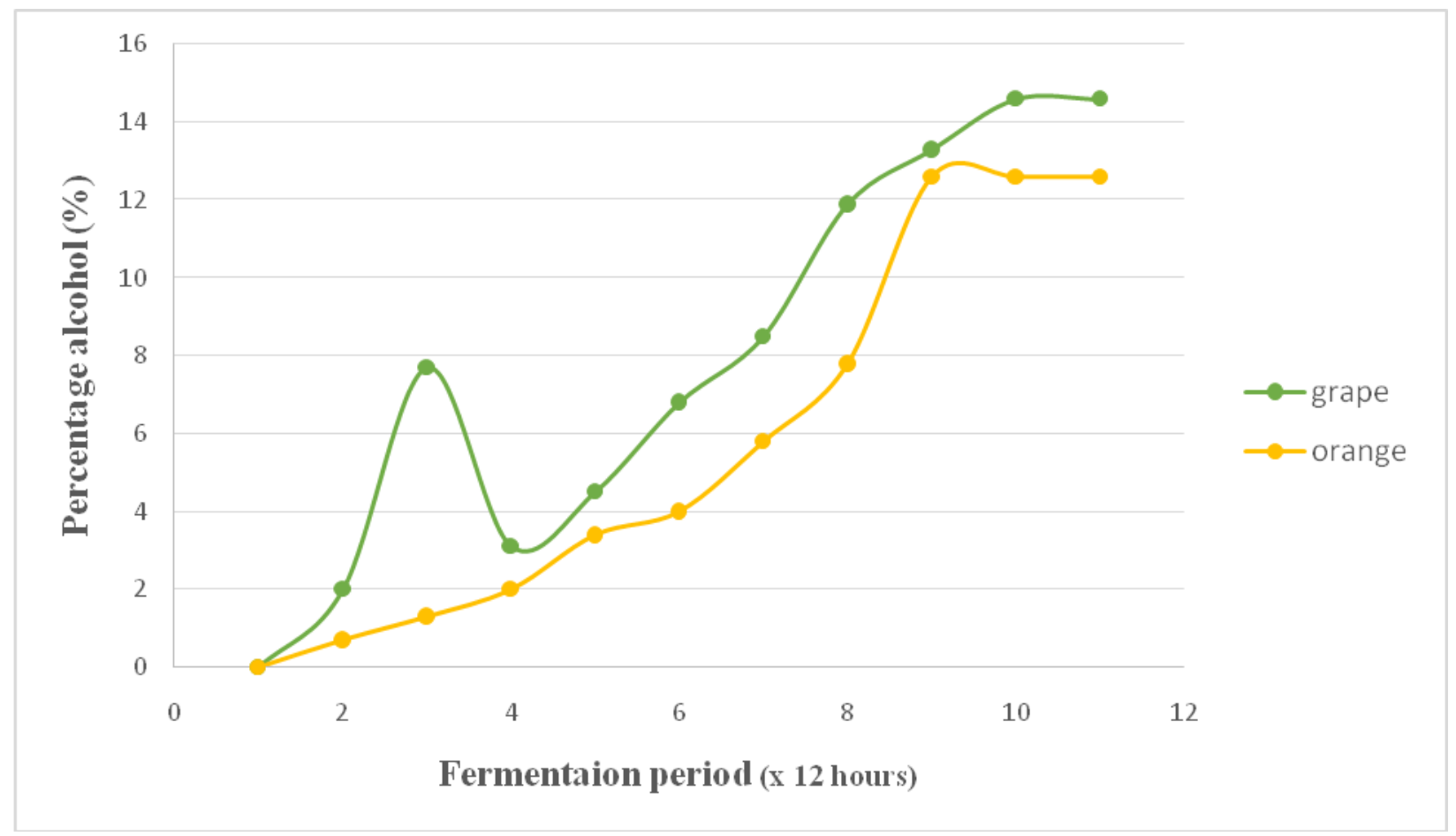

Fig.7 Variation in Total Viable Yeast Count during Fermentation of the Fruits Must

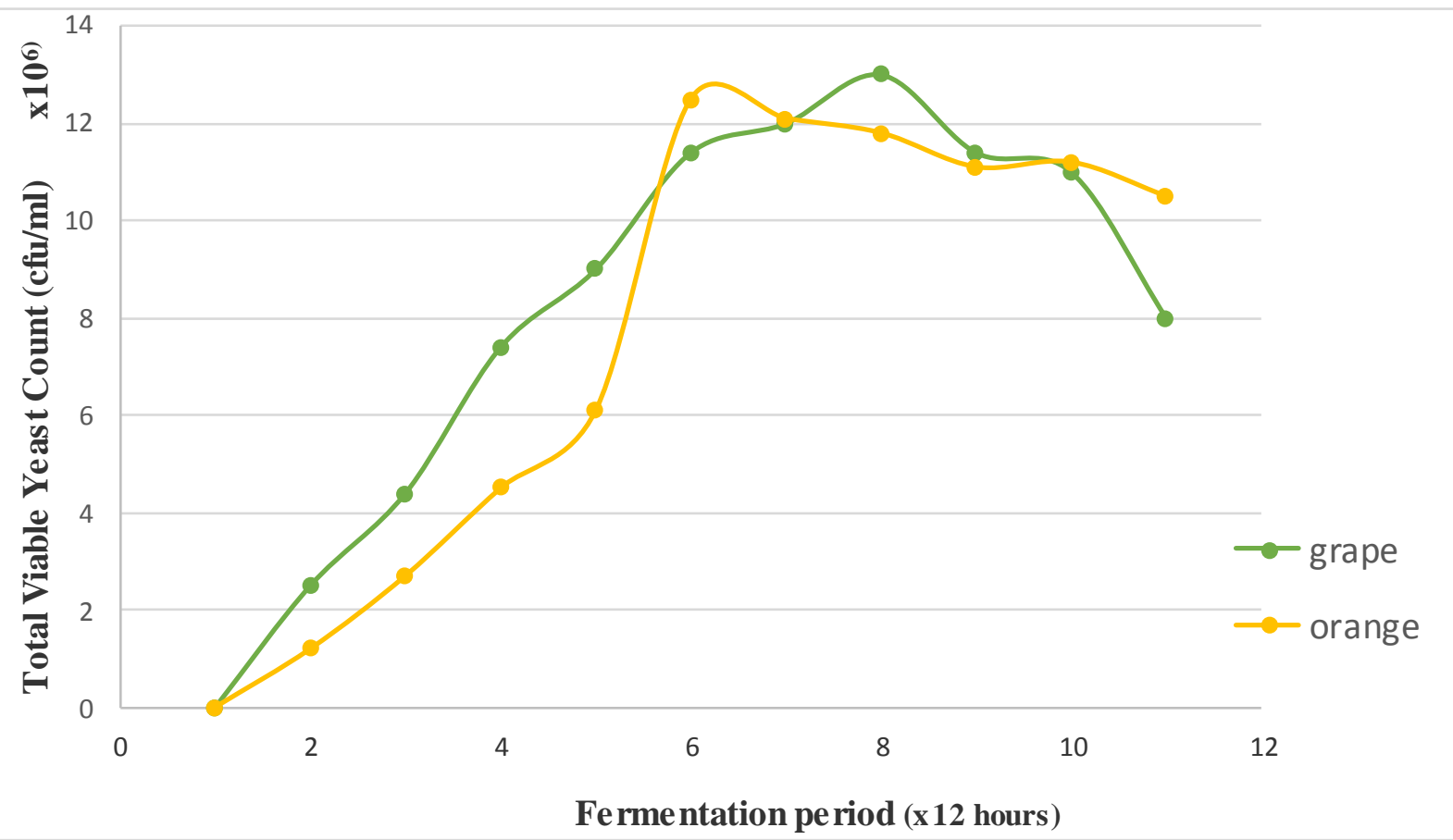


The effectiveness of theSaccharomyces cerevisiae on Vitis vinifera and Citrus seninsis fruits wine fermentation with characteristic ability to complete fermentation; is probably due to its high ethanol tolerance; hence, resulted in production of generally acceptable flavor, taste, and coloured fruits wines.

In conclusion, the grape and orange fruits wines were produced from the Saccharomyces cerevisiae. The fermentation of the grape and orange fruits must result to production of wines with high percentage alcohol content and generally acceptable flavor, taste, and colour. The $\mathrm{pH}$ level of all the fruits wines all fall within acceptable limits and there was no significant difference $(\mathrm{P}>0.05)$ between the $\mathrm{pH}$ of the fruits wines. This study therefore indicates that Saccharomyces cerevisiae strain isolated from the locally tapped palm wine has good fermentative performance and can therefore be used to make fruits wines. However, process optimization and scale up will be required; and hence starter culture obtained to augment for the more expensive and nonavailable commercial wine Saccharomyces cereviciae for better application in wine making.

\section{References}

Alobo, A.P., and Offonry, S.U. 2009. Characteristics of coloured wine produced from roselle (Hibiscus sabdariffa) calyx extract. J. Institute of Brewing, 115(2): 91-94.

Association of Analytical Communities International. 2000. Official Methods of Analysis of wine . AOAC International USA: AOAC International press. pp. 25-30.

Bechem, E.E.T., Omoloko, C. Nwaga, D. and Titanji, V.P.K. 2007. Characterisation of palm wine yeasts using osmotic, ethanol tolerance and the isozyme polymorphism of alcohol dehydrogenase. African J. Biotechnol., 6(14): 1715-1719.

Bellman, R.B. and Gallander, J.F. 2009. Wine deacidification in Chichester, Advance in Food Res., Academic press pp. 3.

Butz, E. 2007. Practical considerations for managing wine acidity. Proceedings of the Spring.

Clemente, J. M., Mingorance, C. L., Martíne, R., Heras, F. J., and Rodríguez, V. S. 2007. Influence of sequential yeast mixtures wine fermentation. Int. $J$. Microbiol., 301-308.

Chilaka, C.A., Uchechukwu, N., Obidiegwu, J.E. and Akpor, O.B. 2010. Evaluation of the efficiency of yeast isolates from palm wine in diverse fruit wine production. African J. Food Sci., 4(12): 764-774.

Hodgson, R.T. 2008. An examination of judge reliability at a major US wine competition. J. Wine Economics, 3(2): 105-113.

Ihekoroye, A.I., Ngoddy, P.O. 1985. Integrated Food Science and Technology for the Tropics Macmillan Publisher, London.

Kelebek, H., Selli, S., and Canbas, A. 2013. HPLC determination of organic acids, sugars, phenolic compositions and antioxidant capacity of orange juice and orange wine. Microchem. J., 91(2): 187-192.

Mir, N.A., and Mohammed, M.K. 2014. Screening, identification and characterization of alcohol tolerant potential bioethanol producing yeasts. Curr. Res. Microbiol. Biotechnol., 2(1): 316-324.

Moronkola, B.A., Olowu, R.A., Tovide, O.O. and Ayejuyo, O.O. 2011. Determination of proximate and mineral contents. $S c$. Revs. Chem.Commum., 1(1): 1 - 6

Naknean, P., Meenune, M. and Roudaut, G. 
2010. Characterization of palm sap harvested in Songkhla province, Southern Thailand. Int. Food Res. J., 7 (4): 977-986.

Nwachukwu, I. N., Ibekwe, V. I., Nwabueze, R.N. and Anyanwu, B. N. 2006. Characterization of palm wine yeast isolates for industrial utilization. African J. Biotechnol., 5(19): 17251728.

Ochai, J.O. and Kolhatkar, A. 2008. Medical Laboratory Science and Practice. Tata McGrew Hill Publishing Limited New Delhi, New York. pp 50-53, 803.

Okaka, J.C. 2010. Tropical Plant Perishable Processing, Storage and handling. New Heaven, 55-60.

Okegbile, E.O., and Taiwo, E.A. 2009. The Nutritional potential of black velvet, Nigerian J. Nutritional Sci., 115-121.

Okoro, C.E. 2007. Production of red wine from roselle (Hibiscus sabdariffa) and pawpaw (Carica papaya) using palmwine yeast (Saccharomyces cerevisiae). Nigerian Food J., 25(2): 158-164.

Okunowo , W.O., and Okotore, R.S. 2005. The alcoholic fermentative efficiency of indigenous yeast strains of different origin. African J. Biotechnol., 4(11): 1290-1296.

Oyeleke, F.I. Olaniyan, A.M. 2007. Extraction of juice from some tropical fruits using a small scale multi-fruit juice extractor. African Crop Sci. Processing J., 8: 1803-1808.

Pearson, D. 2007. The Chemical Analysis of Foods. Churchill Living, 56-89.

Reddy, L.V., and Reddy, O.V. 2009. Production and optimization and characterization of wine from mango. Natural Product J., 426-435.

Steger, C., and Lambrechts, M.G. 2010. The selection of yeast strains for fermention of fruit wine. J. Industrial Microbiol. and Biotechnol., 24(6): 431-440.

Thais, M.G., \& Danilo, G.M. 2006. Isolation and Characterization of Saccharomyces cerevisiae strains. Brazilian $J$. Pharmaceutical Sci., 4-6.

Ukuru, M.U. and Awah J.I. 2013. Properties of palm wine yeasts and its performance in wine making. African J. Biotechnol., 12(19): 2670-2677

\section{How to cite this article:}

Bobai, Mathew, Mohammed, Sani Sambo Datsugwai, Emmanuel, Silas David and Ugboko, Harriet. 2017. Production of Wine from Fermentation of Grape (Vitis vinifera) and Sweet Orange (Citrus seninsis) Juice using Saccharomyces cerevisiae Isolated From Palm Wine. Int.J.Curr.Microbiol.App.Sci. 6(1): 868-881. doi: http://dx.doi.org/10.20546/ijcmas.2017.601.103 